NBER WORKING PAPER SERIES

\title{
THE ECONOMIC COSTS OF CONFLICT: A CASE-CONTROL STUDY FOR THE BASQUE COUNTRY
}

\author{
Alberto Abadie \\ Javier Gardeazabal \\ Working Paper 8478 \\ http://www.nber.org/papers/w8478 \\ NATIONAL BUREAU OF ECONOMIC RESEARCH \\ 1050 Massachusetts Avenue \\ Cambridge, MA 02138 \\ September 2001
}

We thank Josh Angrist, Adolfo de Motta, Esther Duflo, Jim Heckman, Dani Rodrik, Gonzalo Rubio, Emmanuel Saez, Jaume Ventura, and Richard Zeckhauser for helpful comments and discussions. David López-Salido, Mikel Tapia, and Fernando Tusell helped us obtain the financial data. Henry Aray, Francisco Blanch, Sara Piccicuto, and Elena Zoido provided expert research assistance and contributed comments. Gardeazabal thanks the Department of Economics at the University of California, Santa Cruz for its hospitality while part of this work was carried out. The views expressed herein are those of the authors and not necessarily those of the National Bureau of Economic Research.

(C) 2001 by Alberto Abadie and Javier Gardeazabal. All rights reserved. Short sections of text, not to exceed two paragraphs, may be quoted without explicit permission provided that full credit, including $(\subset$ notice, is given to the source. 
The Economic Costs of Conflict: A Case-Control Study for the Basque Country Alberto Abadie and Javier Gardeazabal

NBER Working Paper No. 8478

September 2001

JEL No. D74, G14, O52, P16

\begin{abstract}
$\underline{\text { ABSTRACT }}$
This paper investigates the economic effects of conflict, using the terrorist conflict in the Basque Country as a case study. Our analysis rests on two different strategies. First, we use a combination of other regions to construct a "synthetic" control region which resembles many relevant economic characteristics of the Basque Country before the outset of political terrorism in the 1970's. The subsequent economic evolution of this "counterfactual" Basque Country without terrorism is compared to the actual experience of the Basque Country. We find that, after the outbreak of terrorism, per capita GDP in the Basque Country declined about 10 percent points relative to the synthetic control region. Moreover, this gap seemed to widen in response to spikes in terrorist activity. The second part of this study uses the truce declared in September 1998 as a natural experiment to estimate the effects of the conflict. If the terrorist conflict was perceived to have a negative impact on the Basque economy, stocks of firms with a significant part of their business in the Basque Country should have shown a positive relative performance as the truce became credible, and a negative relative performance at the end of the cease-fire. We find evidence that is consistent with this conjecture using event study methods.
\end{abstract}

Alberto Abadie

John F. Kennedy School of Government

Harvard University

Cambridge, MA 02138

and NBER

alberto_abadie@harvard.edu
Javier Gardeazabal

Department of Economics

University of the Basque Country

48014 Bilbao, Spain

jepgamaj@bs.ehu.es 
Political instability is believed to have strong adverse effects on economic prosperity. However, to date, the evidence on this matter is scarce; probably because it is difficult to know how economies would had evolved in absence of political conflicts.

This article investigates the economic impact of conflict, using the terrorist conflict in the Basque Country as a case study. The Basque conflict is especially interesting from an economic perspective. At the outset of terrorist activity in the early 1970's, the Basque Country was one of the richest regions in Spain, occupying the third position in per capita GDP (out of 17 regions). In the late 1990's, after 30 years of terrorist and political conflict, the Basque Country had dropped to the sixth position in per capita GDP. ${ }^{1}$ During that period, terrorist activity by the Basque terrorist organization ETA resulted in almost 800 deaths. Basque entrepreneurs and corporations had been specific targets of violence and extortion (including assassinations, robberies and kidnappings-for-ransom). Not surprisingly, the economic downturn suffered by the Basque economy during these years has been attributed, at least partially, to the effect of terrorism. However, to the best of our knowledge, almost no research has been carried out to assess the economic effects of the conflict. $^{2}$

This type of study is difficult. On the one hand, a pure time series analysis of the severity of terrorism and the evolution of the Basque economy will be contaminated by the economic downturn which Spain suffered during the second half of the 1970's and the first half of the 1980's, at the peak of terrorist activity. On the other hand, at the outset of terrorism, the Basque Country differed from other Spanish regions in characteristics that are thought to be related to potential for economic growth. Therefore, a simple comparison of the evolution of the Basque economy and the economy of the rest of Spain would not only reflect the effect of terrorism but also the effect of pre-terrorism differences in economic growth determinants.

Our analysis rests on two different strategies. First, we use a combination of other Span-

\footnotetext{
${ }^{1}$ See Fundación BBV (1999).

${ }^{2}$ The only exceptions that we are aware of are Enders and Sandler $(1991,1996)$ who study the effects of terrorism on tourism and foreign direct investment in Spain.
} 
ish regions to construct a "synthetic" control region which resembles most of the relevant economic characteristics of the Basque Country before the outset of Basque political terrorism in the 1970's. The subsequent economic evolution of this "counterfactual" Basque Country without terrorism is compared to the actual experience of the Basque Country. We find that, after the outbreak of terrorism, per capita GDP in the Basque Country declined about 10 percent points relative to the synthetic control region. Moreover, this gap seemed to widen in response to spikes in terrorist activity. The second part of this study uses the unilateral truce declared by ETA in September 1998 as a natural experiment to estimate the effects of the conflict. If the terrorist conflict was perceived to have a negative impact on the Basque economy, stocks of firms with a significant part of their business in the Basque Country should have shown a positive relative performance as the truce became credible, and a negative relative performance at the end of the cease-fire. We find evidence that is consistent with this conjecture using event study methods.

Most of the empirical literature on the effects of political conflict on economic variables have used cross-sections of country-level data. Using a cross-section of countries, Alesina and Perotti (1996) and Venieris and Gupta (1986) concluded that political instability has a negative effect on investment and savings. Also using a cross-section of countries, Alesina et al. (1996), Barro (1991), and Mauro (1995) have argued that political instability has a negative effect on economic growth. ${ }^{3}$ A potential caveat of this literature is that part of the observed association between political conflict and economic variables across countries is thought to be created by reverse causation, since political instability is not only a cause but also an effect of fluctuations in economic variables. ${ }^{4}$ Instrumental variables techniques can be used to correct for reverse causation. However, the validity of instruments in cross-country regressions has often been questioned. ${ }^{5}$ Another potential shortcoming of studies based on country-level data is that political conflicts in different countries may be

\footnotetext{
${ }^{3}$ See also Behhabib and Rustichini (1996), Gupta (1990), Hibbs (1973), and Londregan and Poole (1990) on the relationship between political instability and economic variables.

${ }^{4}$ Conventionally, it has been argued that economic growth promotes political stability. Olson (1963) has argued, however, that rapid economic growth produces social dislocation and it may cause political unrest.

${ }^{5}$ See, e.g., Mankiw (1995).
} 
radically different in nature. Such heterogeneity may create problems when comparing the experiences of different countries and interpreting the results.

Case studies, like the one presented in this paper, look like the natural avenue to validate or refute the results given by cross-country studies.

\section{A Brief History of ETA's Terrorist Activity}

ETA was founded in 1959 to promote the establishment of an independent Basque state. ${ }^{6}$ However, it was not until 1968 when ETA produced its first victim. In fact, ETA did not implement a large scale terrorist activity until the mid 1970's. Table 1 shows the number of killings and kidnappings from 1968 to 2000. ETA's terrorist activity was low before 1973 with no more than 2 victims in any given year. The death toll increased sharply during the mid 1970's, with an average of almost 16 victims per year in the period of 1974-1977. The bloodiest three years of ETA, 1978-1980, witnessed a total of 235 victims. In subsequent years, the number of killings decreased gradually. On average, during the 1980's, ETA's activity resulted in 39 deaths per year; this figure was reduced to 16 per year during the 1990's. The number of kidnappings during the sample period was smaller than the number of killings but evolved similarly. In September 1998, ETA declared a total and indefinite cease-fire. The cease-fire lasted approximately 14 months; in November 1999, ETA announced the end of cease-fire. In the year 2000, ETA killed 23 persons.

In order to finance its operations, ETA has used kidnappings-for-ransom, extortion, and (less frequently) robberies. The main targets of such money-rising activities have been Basque entrepreneurs, who have since begun to abandon the Basque Country in large numbers in order to escape extortion or abduction by the terrorist group. In addition, the terrorist conflict has been frequently cited as a deterrence for domestic and foreign direct investment in the Basque Country (see, e.g., The Economist, Nov. 25, 2000).

Finally, although terrorist attacks have occurred in almost all Spanish regions, most of

\footnotetext{
${ }^{6}$ Basques are spreaded over the Basque Autonomous Region and Navarra in Spain, and part of the French Atlantic Pyrenees Department. The Basque Autonomous Region in Spain has been, however, the main scenario of the conflict; for the rest of the paper, we use the term "the Basque Country" to refer to this region.
} 
ETA's violent activity has been concentrated in the Basque Country (Spanish Ministry of Interior (2000)). ${ }^{7}$

\section{il. Using Other Spanish Regions to Construct a "Synthetic" Basque COUntry Without Terrorism}

The goal of this section is to assess the impact that terrorism has had on economic growth for the Basque Country. Table 2, in columns (1) and (2), reports values of some variables typically associated with growth potential, ${ }^{8}$ for the Basque Country and Spain for the immediate pre-terrorism years. During the 1960's, relative to the whole country, the Basque Country had higher per capita income, higher investment ratio (investment/production), was more densely populated, had a higher percentage of industrial production, and a better educated labor force. As a result, a simple comparison between the Basque Country and the rest of Spain during the terrorism years may not only reflect the impact of terrorism, but also other pre-terrorism differences which affected subsequent economic growth.

We approach this problem by comparing the economic evolution of the Basque Country during the terrorist era with that of a weighted combination of other Spanish regions chosen to resemble the characteristics of the Basque Country before terrorism. We conceptualize such weighted average of other Spanish regions as a "synthetic" Basque Country without terrorism, against which we can compare the actual Basque Country with terrorism. Let $J$ be the number of available control regions and $W=\left(w_{1}, \ldots, w_{J}\right)^{\prime}$ a $(J \times 1)$ vector of non-negative weights which sum to one. The scalar $w_{j}(j=1, \ldots, J)$ represents the weight of region $j$ in the synthetic Basque Country. Each different value for $W$ produces a different synthetic Basque Country, and therefore the choice of a valid subset of control regions is embedded in the choice of the weights $W$.

As said above, the weights are chosen so that the synthetic Basque country most closely resembles the actual one before terrorism. Let $X_{1}$ be a $(K \times 1)$ vector of pre-terrorism values of $K$ economic growth predictors for the Basque Country (i.e., those values in Table

\footnotetext{
${ }^{7}$ See also Kurlansky (1999) and CNN (2001) for background information on the Basque conflict.

${ }^{8}$ See, e.g., Barro and Sala-i-Martin (1995).
} 
2, column (1)). Let $X_{0}$ be a $(K \times J)$ matrix which contains the values of these same variables for the $J$ possible control regions. Let $V$ be a diagonal matrix with non-negative components. The values of the diagonal elements of $V$ reflect the relative importance of the different growth predictors. The vector of weights $W^{*}$ is chosen to minimize $\left(X_{1}-\right.$ $\left.X_{0} W\right)^{\prime} V\left(X_{1}-X_{0} W\right)$ subject to $w_{j} \geq 0 \quad(j=1,2, \ldots, J)$ and $w_{1}+\cdots+w_{J}=1$. The vector $W^{*}$ defines the combination of non-terrorism control regions which best resembled the Basque Country in economic growth determinants at the outset of terrorism. Since $W^{*}$ depends on $V$ there is something to be said about the choice of $V$. Arguably, the choice of $V$ could be subjective, reflecting our previous knowledge about the relative importance of each particular growth predictor. Here, we adopt a more eclectic method, choosing $V$ such that the real per capita GDP path for the Basque Country during the 1960's is best reproduced by the resulting synthetic Basque Country (see Appendix B for details).

The reason to restrict the weights in $W$ to be non-negative and sum to one is to prevent extrapolation outside the support of the growth predictors for the control regions. Without this restriction (and if all the diagonal elements of $V$ are positive), $X_{1}$ would be perfectly fitted as long as the rank of $X_{0}$ is equal to $K$. When the weights in $W$ are restricted to be non-negative and sum to one, $X_{1}$ cannot be perfectly fitted in general even if the rank of $X_{0}$ is equal to $K .{ }^{9}$ Column (3) of Table 2, reports growth predictors for the synthetic Basque Country before terrorism: $X_{1}^{*}=X_{0} W^{*}$. These figures give an indication of how well the weighted combination of control regions reproduces the values of growth predictors for Basque Country before terrorism. As expected, the synthetic Basque Country looks comparable to the actual one, although some growth determinants cannot be perfectly fitted. In particular, during the 1960's, the Basque Country was the Spanish region with the highest industrial share as a percentage of total production. Therefore, a convex combination of other Spanish regions cannot perfectly reproduce the Basque sectoral shares before terrorism.

Let $Y_{1}$ be a $(T \times 1)$ vector whose elements are the values of real per capita GDP for

\footnotetext{
${ }^{9} X_{1}$ will be perfectly fitted only if it lies in the "support" (convex hull) of the growth predictors for the control regions.
} 
the Basque Country during $T$ time periods. Let $Y_{0}$ be a $(T \times J)$ matrix which contains the values of the same variables for the control regions. Our goal is to approximate the per capita GDP path that the Basque Country would have experienced in the absence of terrorism. This counterfactual per capita GDP path is calculated as the per capita GDP of the synthetic Basque Country, $Y_{1}^{*}=Y_{0} W^{*}$.

Figure 1 plots $Y_{1}$ and $Y_{1}^{*}$ for the period 1955-1997. The Basque Country and the synthetic control behave similarly until 1975. From 1975, when ETA's terrorist activity becomes a large-scale phenomenon, $Y_{1}$ and $Y_{1}^{*}$ diverge; the Basque Country per capita GDP takes values up to around $12 \%$ below those of the synthetic control. The gap in per capita GDP seems to decrease at the end of the period, taking values around 8\%-9\% in 1995-97. Overall, Figure 1 suggests a 10\% loss in per capita GDP due to terrorism for the 1980's and 1990's.

Of course, a question remains about whether the estimated gap truly responds to the effect of terrorism or is merely an artifact of the inability of the control regions to reproduce the growth path for the Basque Country in the absence of terrorism. We approach this question from two different angles. First, we analyze the statistical relationship between the estimated gap and the intensity of terrorism. Second, we perform a "placebo study," applying the same analysis to a "non-terrorism region" (a region other than the Basque Country).

Since production factors are fixed in the short run, we expect terrorism to have a lagged negative effect on per capita GDP. In Figure 2, we plotted the estimated GDP gap as a percentage of Basque GDP $\left(100 \times\left(Y_{1}-Y_{1}^{*}\right) / Y_{1}\right)$ and the number of deaths caused by terrorist actions (used as a proxy for overall terrorist activity). As expected, spikes in terrorist activity seem to be followed by increases in the amplitude of the GDP gap. This pattern is confirmed by Figure 3 which shows the estimated impulse-response function of terrorism on the GDP gap. The impulse-response function shows the estimated contemporaneous and lagged response of per capita GDP gap to an increase of terrorist activity, proxied by an increase of one unit in the number of victims per year (see Appendix 
$\mathrm{B}$ for details on the estimation of the impulse-response function). The effect of terrorism on the GDP gap is negative for every time lead, it is maximal after two to three years, and it decreases monotonically (in absolute value) after that. Terrorist activity explains the GDP gap almost perfectly (see last row of Table A.1 in Appendix B), and it does so in a way that is consistent with our previous beliefs about the lagged impact of terrorism on output.

An alternative way to check if the estimated GDP gap is generated spuriously by the analytical methods that we adopted is to apply the same techniques to a control region. To conduct this "placebo" study we chose Catalonia which was the region with the largest weight in the synthetic control for the Basque Country (see Appendix B). In addition to being the region most similar (under our methodology) to the Basque Country before terrorism, Catalonia resembles the Basque Country in many characteristics, some of which are not directly measured in our data. In particular, at the end of Franco's dictatorship, both the Basque Country and Catalonia were highly industrialized regions, and both had historical demands for self-governance, which led to the first two regional autonomy statutes of the post-Franco era in 1979. Since then, autonomy statutes have been granted to the rest of Spanish regions, however Catalonia and the Basque Country have always been among the regions with the highest degree of political autonomy. While in both regions large fractions of the population have traditionally demanded higher levels of self-governance, Catalonia never experienced a large-scale outbreak of political terrorism. Figure 4 shows the actual real per capita GDP path for Catalonia and the one implied by a "synthetic Catalonia" constructed as a weighted combination of other Spanish regions (excluding the Basque Country) as explained above. The weighted combination of Spanish regions reproduces per capita GDP for Catalonia with high accuracy up to the late 1980's. During 1990-1997 Catalonia over-performed the synthetic control by around $4 \%$ in per capita GDP. This gap does not come as a surprise if we consider the heavy investments and economic expansion that Catalonia experienced during that period as a result of the 1992 Summer Olympic Games hosted in Barcelona. Since Catalonia is the main contributor to the synthetic 
control for the Basque Country, an abnormally high level of per capita GDP for Catalonia during the 1990's may artificially widen the GDP gap for the Basque Country in Figure 1. Therefore, our placebo study suggests that, while GDP per capita for Catalonia can be reasonably well reproduced by our techniques, the catch-up in per capita GDP for the Basque Country during the 1990's (relative to the synthetic control region) may have been more pronounced than what Figure 1 indicates.

As noted earlier, the Basque Country has been the main scenario of the terrorist conflict. However, ETA has also operated in other Spanish regions. Even though there is no indication that entrepreneurs have abandoned Spain as a result of the terrorist threat, Basque terrorism might have imposed a negative reputational externality on other Spanish regions, and foreign investment might have chosen alternative destinations with no terrorist conflicts. If it is in fact the case that the Basque terrorist conflict has had a negative economic effect on other Spanish regions, this effect is arguably weaker than the economic effect of terrorism on the Basque Country. To the extent that the regions which form the synthetic control might have been economically hurt by the conflict, our estimated GDP gap would provide a lower bound on the economic effect of terrorism on the Basque Country economy. On the other hand, the conflict may have diverted investment from the Basque Country to other Spanish regions biasing our estimated gap upwards. However, since the size of the synthetic Basque Country is much larger than the actual Basque Country, this type of bias is arguably small. ${ }^{10}$ In the next section we show evidence that support the view that the effect of the conflict was small outside the Basque Country.

A more important criticism of the analysis in this section is that, as long as the synthetic control cannot reproduce exactly the characteristics of the Basque Country before terrorism, the GDP gap may have been created by differences in growth predictors between the Basque Country and the synthetic control before terrorism (columns (1) and (3) in Table 2). In particular, it might be argued that the GDP gap was caused by the higher industrial concentration in the Basque Country in the pre-terrorism years, since terrorism developed

\footnotetext{
${ }^{10}$ For the 1964-1975 period, GDP for the synthetic region was 2.5 times larger than GDP for the Basque Country, this figure increased to more than 3 during the terrorism era.
} 
during a period of industrial decline, when many industrial plants closed. In fact, the industrial share of GDP declined 17 percentage points (from 45\% to 28\%) for the Basque Country during the 1964-1993 period. The industrial share of the GDP decreased 15 percentage points (from 38\% to 23\%) for the synthetic control during the same period. Notwithstanding the potential importance of this criticism, we believe that differences in industrial decline between the Basque Country and the synthetic control cannot fully explain the GDP gap between the two regions during the 1980s and 1990s. As discussed earlier, the GDP gap seems to respond to the intensity of the the terrorist activity in the Basque Country. Such association is consistent with the interpretation that the gap was caused by terrorism, and would be left unexplained under the alternative explanation that the gap was generated by a more pronounced industrial decline in the Basque Country.

Figure 5 graphs population series for the Basque Country, the synthetic control and Spain (the series are normalized to 100 in 1964). The population of the Basque Country and the synthetic control grew at similar rates during the late 1960s and the early and the mid 1970s, well above the rate for the whole country. In the late 1970s and early 1980s the patterns of the series changed dramatically; population growth decelerated for the synthetic Basque Country and Spain, and became negative for the Basque Country. The results on per capita GDP gap presented in this section do not reflect this relative population loss in the Basque Country. Once the population dynamics are considered, the gap in per capita GDP documented in this section becomes even more striking.

Finally, it is worth noticing that the results in this section are consistent with the findings in Barro and Sala-i-Martin (1995, page 399, Figure 11.8) who document an atypically low growth rate for the Basque Country during the period 1950-1999 relative to other European regions.

\section{Using ETA's 1998-1999 Truce AS A NATURAl Experiment}

On September 16, 1998, ETA announced a cease-fire (starting on September 18, 1998). Fourteen months later, on November 28, 1999, ETA announced the end of the truce. Table 3 presents a chronology of some of the most important events related to the truce. Anecdotal 
evidence suggests that the truce was not perceived as credible from the beginning (note, for example, the Spanish government's reaction to the announcement of the cease-fire in Table 3, event number 4). In fact, ETA had declared other cease-fires in the past, but none of them lasted more than three months; the previous one, in 1996, had only lasted one week. Peace prospects became more realistic as months passed without terrorist actions and the Spanish government confirmed contacts with ETA. Weeks before the end of the truce the situation deteriorated as the Spanish government announced that the process was paralyzed.

If financial markets are efficient, asset prices should reflect all available information and, thus, react only to new information. Therefore, if the terrorist conflict was perceived to have a negative impact on the Basque economy, Basque stocks (stocks of firms with a significant part of their business in the Basque Country) should have shown a positive performance relative to non-Basque stocks (stocks of firms without a significant part of their business in the Basque Country) as the truce became credible. Similarly, Basque stocks should have performed poorly, relative to non-Basque stocks, at the end of the truce. In this section, we use the method of event study to explore these questions.

A challenge with this exercise is that there is no obvious way to classify stocks into the Basque/non-Basque categories. A classification that relies solely on companies' registered addresses seems problematic. Registered addresses are sometimes chosen for historic, convenience, or tax-related reasons and do not necessarily imply that the company has an important presence in the area. Unfortunately, data on geographical location of firms' activities are rarely available. To solve this problem we adopted a simple and direct approach. Since what is relevant for our event study is which companies were perceived by the markets as carrying a significant part of their business in the Basque Country, we asked a group of market analysts at a certain Basque financial institution to produce this classification for us. We used this information to divide stocks into Basque stocks and non-Basque stocks. Again, the idea is to label firms which have a large part of their business in the Basque Country as Basque stocks, even if they are not located in the Basque County. All other 
firms with little exposure in the Basque Country were labeled as non-Basque stocks. ${ }^{11}$

We collected series of daily stock returns for 1998, 1999 and 2000 and constructed two buy-and-hold portfolios: one composed of 14 Basque stocks and the other composed of 59 non-Basque stocks (see Appendix B for details on selection of stocks for our sample and construction of portfolios). Buy-and-hold portfolios represent the portfolio of a passive investor who constructed a value-weighted Basque or non-Basque portfolio at the beginning of our sample. ${ }^{12}$

Table 4 contains descriptive statistics for our sample. Fifty-seven percent of the firms that compose our Basque portfolio have registered addresses in the Basque Country, while none of the non-Basque firms are registered in the Basque Country. On average, Basque firms are smaller and have a higher book-to-market ratio. ${ }^{13}$

In contrast with more conventional event study settings, where most of the information is revealed during short event windows, the informational content of the truce evolved gradually during a 14 month period. Therefore, to study the effect of the truce is important to control for long-run risk factors in stock returns. The empirical finance literature (see, e.g., Fama and French 1993, and Lyon et al. 1999) has shown that common risk in stock returns is fairly well explained by the so-called Fama-French Three-Factor Model:

$$
R_{t}^{j}=\alpha^{j}+\beta_{1}^{j} R_{t}^{m}+\beta_{2}^{j} S M B_{t}+\beta_{3}^{j} H M L_{t}+A R_{t}^{j} .
$$

$R_{t}^{j}$ is the excess return (over the risk free rate) on a buy-and-hold portfolio of $j=$ Basque, non-Basque stocks on day $t, R_{t}^{m}$ is the excess return on the market portfolio at time $t, S M B_{t}$ ("small minus big") is the difference between the returns of portfolios composed by small and big size stocks at time $t$, and $H M L_{t}$ ("high minus low") is the dif-

\footnotetext{
${ }^{11}$ The list of Basque and non-Basque stocks used for the analysis is provided in Appendix B, Table A.2.

${ }^{12}$ The strategy of constructing portfolios of firms exposed and not exposed to certain risks is often used in event studies. See for instance Kho, Lee, and Stulz (2000). By using buy-and-hold portfolios we avoid "rebalancing" bias (the bias induced by the rebalancing necessary to maintain a value-weighted or equallyweighted portfolio). In addition, since we only consider stocks with data available for the whole sample period, the analysis does not suffer from "new listings" bias (the bias induced by the reweighting necessary because new stocks enter the market or some exit). See Lyon, Barber, and Tsai (1999).

${ }^{13}$ Size is the market valuation of a common stock. The book-to-market ratio is the ratio of the book value of a stock to its market value.
} 
ference between the returns of portfolios composed by high and low book-to-market stocks at time $t$.

$R_{t}^{m}$ represents the usual market factor in stock returns, while $S M B_{t}$ and $H M L_{t}$ are meant to capture risk factors related to size and book to market equity respectively. The residual, $A R_{t}^{j}$, is a zero mean abnormal portfolio return not explained by common risk factors. ${ }^{14}$

Columns (1) and (2) of Table 5 report the results of fitting equation (1) by OLS to the Basque and non-Basque portfolios. The coefficients on $R_{t}^{m}, S M B_{t}$ and $H M L_{t}$ are all significant. The coefficients on $R_{t}^{m}$ are positive in both cases, whereas the coefficients on $S M B_{t}$ and $H M L_{t}$ have positive signs for the Basque portfolio and negative signs for the non-Basque portfolio. This result is in line with Fama and French (1993) who find that returns of portfolios constructed from stocks with small market valuation and high book-tomarket (as the Basque portfolio) respond positively to $S M B_{t}$ and $H M L_{t}$, whereas returns of portfolios constructed from stocks with big market valuation and low book-to-market (as the non-Basque portfolio) respond negatively to $S M B_{t}$ and $H M L_{t}$.

The residuals of the regressions are the estimated abnormal returns on the Basque and non-Basque portfolios. Abnormal returns are now suited for comparison, as they are adjusted for known risk factors. However, abnormal returns are too noisy to be visually instructive. In order to visually inspect the difference in performance of the two portfolios abnormal returns are customarily aggregated through time. We calculate cumulative abnormal returns as the compounded abnormal return of a portfolio from the day after the announcement of the truce:

$$
C A R_{t}^{j}=\left(\prod_{s=1}^{t}\left\{1+A R_{s}^{j}\right\}\right)-1 .
$$

Figure 6 graphs cumulative abnormal returns for the Basque and non-Basque portfolios from the beginning of the truce to the end of 1999 (the vertical line in Figure 6 represents the end of the truce). The Basque portfolio over-performs the non-Basque portfolio for most

\footnotetext{
${ }^{14}$ See the influential paper by Fama and French (1993) and Appendix B for more information about the definition and construction of these variables. Lyon et al. (1999) discusses the use of the Fama-French Three-Factor Model to calculate long-run abnormal returns in event studies.
} 
of the truce period except at the beginning (when the cease-fire had not gained credibility) and at the end (when the cease-fire lost credibility).

To perform a statistical test on the effect of the truce we added two dummy variables to equation (1). Good News ${ }_{t}$ takes a value of one for the period between the trading sessions after event 5 and event 7 in Table 3, and a value of zero otherwise. Bad News $t_{t}$ takes a value of one for the period between the trading sessions after event 11 and event 14 in Table 3, and a value of zero otherwise. The Good News period comprises 22 trading sessions and the Bad News period 66. During the Good News period, the credibility of the truce gained ground, starting with the offer of a revision in the policy towards ETA activists in jail, if peace consolidated, by the Spanish Prime Minister (event number 5), and culminating with the announcement of the authorization of direct contacts with ETA by the Spanish government (event number 7). In contrast, the Bad News period was characterized by the collapse of the peace process, starting with the acknowledgment that contacts had been interrupted, made by the Spanish Prime Minister (event number 11), and ending with the announcement of the end of the truce by ETA (event number 14). Columns (3) and (4) of Table 5 report the regressions including the dummy variables Good News and Bad News. The estimated coefficients on the dummy variables represent average daily abnormal returns during the Good News and Bad News periods for the Basque and non-Basque portfolios. As expected, for the Basque portfolio, the coefficient of Good News is positive and significant while the coefficient of Bad News is negative and also significant. For the non-Basque portfolio, the effects are small in magnitude and not statistically different from zero, which supports the view that Basque terrorism has a minor impact on the economy outside the Basque Country. The last column of Table 5 shows the result on the difference regression. The difference regression can be interpreted as the one that corresponds to the portfolio of a passive investor who takes a long position in Basque stocks and a short position in non-Basque stocks. This regression reflects a positive abnormal performance of Basque stocks relative to non-Basque stocks during the Good News period and a negative relative performance during the Bad News period. 


\section{Summary and Conclusions}

Much has been said about the pernicious effects of political conflict on the economy. However, to date, little case study research has been produced on this matter. This paper presents evidence of a negative economic impact of the terrorist conflict in the Basque Country. The first part of this study shows a $10 \%$ average gap between Basque per capita GDP and the per capita GDP of a comparable synthetic region without terrorism which emerges over a period of two decades. Moreover, changes in per capita GDP gap are shown to be associated with the intensity of terrorist activity. The second part of this study uses the 1998-1999 cease-fire as a natural experiment to measure the effect of the conflict on the stock value of a sample of Basque and non-Basque firms. We show that Basque stocks over-performed non-Basque stocks as the truce became credible. At the end of the cease-fire, Basque stocks showed a negative performance relative to non-Basque stocks.

Although we focus here on the Basque conflict, the methods applied in this paper can be used to investigate the economic effects of conflicts elsewhere. The application of the techniques in this paper to the study of other conflicts will also shed light on the robustness of the procedure and serve as a cross validation.

Research of this sort could potentially have an undesirable impact if terrorists learn that their actions affect the economy negatively, assuming that is what they want to do. However, we do hope that, as Nelson and Scott (1992) found that media attention does not cause terrorism, academic attention does not cause terrorism either. 


\section{Appendix A: Data Sources}

Data on terrorist activity (deaths and kidnappings) are provided in Spanish Ministry of Interior (2000). Regional data on GDP, investment, population density, and sectoral production come from Fundación BBV (1999). The regions used for the analysis are the 17 autonomous communities of Spain (leaving out the small autonomous towns of Ceuta and Melilla on the coast of Africa). Data on human capital for different regions have been collected by Mas et al. (1998). One day public debt repurchase agreement rates come from the Bank of Spain. Data on stock prices, firm size (market value of outstanding shares), book equity and dividends are routinely collected by the Madrid Stock Exchange (http://www.bolsamadrid.es).

\section{Appendix B: Technical Details}

Estimation of per capita GDP gap: Consider the problem,

$$
\underset{W \in \mathcal{W}}{\operatorname{minimize}}\left(X_{1}-X_{0} W\right)^{\prime} V\left(X_{1}-X_{0} W\right)
$$

where $\mathcal{W}=\left\{\left(w_{1}, \ldots, w_{J}\right)^{\prime}\right.$ s.t. $\left.w_{1}+\cdots+w_{J}=1, w_{j} \geq 0 \quad(j=1, \ldots, J)\right\}$, and $X_{1}, X_{0}$, and $V$ are as described in the text. The solution to this problem, $W^{*}(V)$, depends on the diagonal matrix $V$ whose diagonal elements are weights which reflect the relative importance of the variables in $X_{0}$ and $X_{1}$. We selected $V$ such that per capita GDP for the Basque country during the 1960's is best reproduced by the synthetic control defined by $W^{*}(V)$. Let $Z_{1}$ be a $(10 \times 1)$ vector containing the real per capita GDP values for the Basque Country during the period 1960-69. Let $Z_{0}$ be $(10 \times J)$ matrix containing the values of the same variables for the $J$ potential control regions. Then

$$
V^{*}=\underset{V \in \mathcal{V}}{\operatorname{argmin}}\left(Z_{1}-Z_{0} W^{*}(V)\right)^{\prime}\left(Z_{1}-Z_{0} W^{*}(V)\right)
$$

where $\mathcal{V}$ is the set of all non-negative diagonal $(K \times K)$ matrices. The weights for the synthetic control are given by $W^{*}=W^{*}\left(V^{*}\right)$. There are infinitely many solutions for $V^{*}$ (if $V^{*}$ is a solution so is $V^{*}(c)=c \cdot V^{*}$ for any positive scalar $c$ ), so we can normalize the Euclidean norm of $V^{*}$ (or any positive diagonal element of $\left.V^{*}\right)$ to one.

The optimal weights, $W^{*}$, are .8508 for Catalonia, .1492 for Madrid and zero for the rest of the regions. Small variations in $V$ generate small positive weights for regions other than Catalonia and Madrid without altering the results substantively.

Estimation of the impulse-response function: Since the number of periods is small we adopted a convenient parameterization to estimate the impulse-response function. We started considering a flexible dynamic model with AR(1) disturbances similar to the one proposed by Harvey (1990, p. 268):

$$
\begin{aligned}
G_{t} & =\mu+\alpha_{1} G_{t-1}+\alpha_{2} G_{t-2}+\beta_{0} D_{t}+\beta_{1} D_{t-1}+\beta_{2} D_{t-2}+u_{t}, \\
u_{t} & =\rho u_{t-1}+\varepsilon_{t}
\end{aligned}
$$

where $G_{t}$ and $D_{t}$ are respectively the per capita GDP gap and number of death victims in period $t$, and $\varepsilon_{t}$ are serially independent shocks. The vector of unknown parameters $\theta=\left(\mu, \alpha_{1}, \alpha_{2}, \beta_{0}, \beta_{1}, \beta_{2}, \rho\right)^{\prime}$ is to be estimated. Note however, that equation (A.1) cannot be directly estimated by least squares, since the error term $u_{t}$ is correlated by construction with $G_{t-1}$ and $G_{t-2}$. Expressing $u_{t-1}$ in term of lags of $G_{t}$ and $D_{t}$ we get:

$$
G_{t}=\pi_{0}+\pi_{1} G_{t-1}+\pi_{2} G_{t-2}+\pi_{3} G_{t-3}+\pi_{4} D_{t}+\pi_{5} D_{t-1}+\pi_{6} D_{t-2}+\pi_{7} D_{t-3}+\varepsilon_{t},
$$

where the vector $\pi=\left(\pi_{0}, \pi_{1}, \ldots, \pi_{7}\right)^{\prime}$ is a nonlinear function of $\theta$. We estimated equation (A.2) consistently by least squares for the period 1955-97. The parameters in $\theta$ were recovered from the estimates of $\pi$ by minimum distance (see, e.g., Newey and McFadden (1994)). The result is reported in Table A.1 column (1). We proceeded sequentially eliminating non-significant parameters in columns (2) to (5), which are 
estimated by least squares. Our preferred specification, which contains terms in $G_{t-1}, G_{t-2}$ and $D_{t-1}$ is reported in column (5). Inverting the autoregressive terms, we obtain the impulse response function:

$$
\delta_{s}=\frac{\partial G_{t+s}}{\partial D_{t}}=\left\{\begin{array}{cc}
0 & \text { if } s=0 \\
\beta_{1} & \text { if } s=1 \\
\alpha_{1} \delta_{s-1}+\alpha_{2} \delta_{s-2} & \text { if } s \geq 2
\end{array}\right.
$$

where $s$ runs over non-negative integers. We report standard errors that are robust to misspecification.

Computation of asset returns: We collected daily end-of-the-day stock prices from Madrid's continuous trading stock exchange market for a sample period from January 2, 1998 to December 29, 2000 for a total of 748 daily observations. We restricted the analysis to firms with complete data for the sample period. This restriction eliminates all firms which entered the market during the sample period, had their quotation suspended or merged with other firm in the data file. This resulted in a sample of 81 firms. During 1998 stock prices were quoted in Spanish pesetas and starting in January 4, 1999, quotations were in euros, thus requiring adjustment by multiplying the euro figures by the 166.386 pesetas/euro fixed exchange rate. Stock prices were also adjusted for splits. Then, daily returns were calculated and adjusted for dividends and equity issue (also adjusted for pesetas/euro conversion and splits). The return on the market portfolio was proxied by the rate of change of the general index of the Madrid Stock Exchange (IGBM) and the risk-free asset return was taken to be the return on the one-day public debt repurchase agreements. To construct the size and book-to-market portfolios, we used end of 1997, 1998 and 1999 book value and market valuation, this information was not available for 7 firms which reduced the sample to 74 firms. Then, we proceed as in Fama and French (1993) to compute the returns on the size and book-to-market portfolios. We first ranked stocks according to market size and the median was used to split the sample in two groups, small (S) and big (B). Then, we classified stocks into three book-to-market groups, the bottom 30\% (Low), middle 40\% (Medium) and top 30\% (High). The size and book-to-market figures used in 1998, 1999 and 2000 correspond to the end of 1997, 1998 and 1999 figures respectively. Then, we constructed six portfolios $(\mathrm{S} / \mathrm{L}, \mathrm{S} / \mathrm{M}, \mathrm{S} / \mathrm{H}, \mathrm{B} / \mathrm{L}, \mathrm{B} / \mathrm{M}$ and $\mathrm{B} / \mathrm{H})$ and computed daily value-weighted returns on those portfolios. The size portfolio used in the regressions is the daily difference between the average return on the small-size portfolios $(\mathrm{S} / \mathrm{L}, \mathrm{S} / \mathrm{M}$ and $\mathrm{S} / \mathrm{H})$ and the average return on the big-size portfolios $(\mathrm{B} / \mathrm{L}, \mathrm{B} / \mathrm{M}$ and $\mathrm{B} / \mathrm{H})$. The book-to-market portfolio is the daily difference between the average return on the highbook-to-market portfolios $(\mathrm{S} / \mathrm{H}$, and $\mathrm{B} / \mathrm{H})$ and the average return on the low-book-to-market portfolios $(\mathrm{S} / \mathrm{L}$ and $\mathrm{B} / \mathrm{L})$.

We then computed calendar time returns on buy-and-hold Basque and non-Basque portfolios. We excluded an additional Basque firm since its market valuation accounted for $75 \%$ of the value of Basque portfolio total market valuation. The Basque portfolio contains 14 stocks and the non-Basque portfolio 59 stocks. Table A.2 provides a list of the stocks in the Basque and non-Basque portfolios.

The buy-and-hold portfolios constructed at the beginning of the sample were value-weighted. There is no rebalancing (buying or selling stocks) in the buy-and-hold portfolios, reflecting a passive investment strategy. Let $V_{i, t}^{j}$ be the market valuation of all shares of stock $i$ held in portfolio $j$ in period $t$. Let $V_{t}^{j}$ be the market valuation of portfolio $j$ at time $t$, that is

$$
V_{t}^{j}=\sum_{i=1}^{n_{j}} V_{i, t}^{j}
$$

where $n_{j}$ is the number of stocks in portfolio $j$. Let $R_{i, t}^{j}$ be the market return of stock $i$ in portfolio $j$ between periods $t-1$ and $t$. The buy-and-hold investment strategy implies that $V_{i, t}^{j}=\left(1+R_{i, t}^{j}\right) V_{i, t-1}^{j}$ for all $t$, hence $V_{t}^{j}=\sum_{i=1}^{n_{j}}\left(1+R_{i, t}^{j}\right) V_{i, t-1}^{j}=V_{t-1}^{j}+\sum_{i=1}^{n_{j}} R_{i, t}^{j} V_{i, t-1}^{j}$. Therefore, the return of portfolio $j$ between periods $t-1$ and $t$ is given by

$$
R_{t}^{j}=\frac{V_{t}^{j}-V_{t-1}^{j}}{V_{t-1}^{j}}=\sum_{i=1}^{n_{j}} R_{i, t}^{j}\left(\frac{V_{i, t-1}^{j}}{V_{t-1}^{j}}\right)=\sum_{i=1}^{n_{j}} R_{i, t}^{j} \omega_{i, t-1}^{j},
$$


where $\omega_{i, t}^{j}=V_{i, t}^{j} / V_{t}^{j}$ is the weight of stock $i$ in portfolio $j$ at time $t$. The evolution of weights over time is described by the following equation,

$$
\omega_{i, t}^{j}=\frac{V_{i, t}^{j}}{V_{t}^{j}}=\frac{\left(1+R_{i, t}^{j}\right) V_{i, t-1}^{j}}{\left(1+\sum_{i=1}^{n_{j}} R_{i, t}^{j}\left(\frac{V_{i, t-1}^{j}}{V_{t-1}^{j}}\right)\right) V_{t-1}^{j}}=\frac{\left(1+R_{i, t}^{j}\right) \omega_{i, t-1}^{j}}{1+\sum_{i=1}^{n_{j}} R_{i, t}^{j} \omega_{i, t-1}^{j}} .
$$

The starting values of the weights were calculated as $\omega_{i, 0}^{j}=M_{i, 0}^{j} / M_{0}^{j}$ where $M_{i, 0}^{j}$ is the total market value of all outstanding shares of stock $i$ in portfolio $j$ in period 0 and $M_{0}^{j}$ is the total market value of all outstanding shares of stocks included in portfolio $j$. Therefore, at the beginning of the sample, the buy-and-hold portfolios were value-weighted portfolios. 


\section{REFERENCES}

Alesina, A., S. Ozler, N. Roubini and P. Swagel. "Political Instability and Economic Growth." Journal of Economic Growth, 1996, 1, 189-211.

Alesina, A. And R. Perotti. "Income Distribution, Political Instability and Investment." European Economic Review, 1996, 40, pp. 1203-1228.

BARro, R. J. "Economic Growth in a Cross Section of Countries." Quarterly Journal of Economics, May 1991, 106(2), pp. 407-43.

Barro, R. J. And X. Sala-I-Martin. Economic Growth. New York: McGraw-Hill, 1995.

Behнabib, J. And A. Rustichini. "Social Conflict and Growth." Journal of Economic Growth, 1996, $1,125-42$.

CNN. Basque Conflict: Violence in Spain, http://www.cnn.com/SPECIALS/2001/basque/, 2001.

Enders, W. And T. SAndler. "Causality between Transnational Terrorism and Tourism: the Case of Spain." Terrorism, 1991, 14(1), pp. 49-58.

Enders, W. And T. SAndler. "Terrorism and Foreign Direct Investment in Spain and Greece." Kyklos, 1996, 49(3), pp. 331-52.

Fama, E. F. And K. R. French. "Common Risk Factors in the Returns on Stocks and Bonds." The Journal of Financial Economics, February 1993, 33(1), pp. 3-56.

Fundación BBV. Renta Nacional de España y su Distribución Provincial. Bilbao: Fundacion BBV, 1999.

Gupta, D.K.. The Economics of Political Violence. New York: Praeger, 1990.

Harvey, A. The Econometric Analysis of Time Series. New York: Philip Allan, 1990.

Hibbs, D. Mass Political Violence: A Cross-Sectional Analysis. New York: Wisley and Sons, 1973.

Kho, B. C., D. Lee And R. M. Stulz. "U.S. Banks, Crises, and Bailouts: from Mexico to LTCM." American Economic Review, May 2000, 90(2), pp. 28-31.

Kurlansky, M. The Basque History of the World. New York: Walker \& Company, 1999.

Londregan, J.B. And K. T. Poole. "Poverty, The Coup Trap, and the Seizure of Executive Power." World Politics, Jan 1990, 42(2), pp. 151-83.

Lyon, J. D., B. M. Barber and C. Tsay. "Improved Methods for Test of Long-Run Abnormal Stock Returns." The Journal of Finance, February 1999, 54(1), pp. 165-201.

Mankiw, G. "The Growth of Nations." Brookings Papers on Economic Activity, 1995, 1, pp. 275-310.

Mas, M., F. Perez, E. Uriel and L. Serrano. Capital Humano, Series Históricas. Valencia: Fundacion Bancaixa, 1998.

Mauro, P. "Corruption and Growth." Quarterly Journal of Economics, 1995, 110(3), pp. 681-712.

Nelson, P. S. And J. L. Scott. "Terrorism and the Media: An Empirical Analysis." Defense Economics, 1992, 3(4), pp. 329-39.

Newey, W. K. and D. McFadden. "Large Sample Estimation and Hypothesis Testing," in R. F. Engle and D. L. McFadden, eds., Handbook of Econometrics, Vol. 4. New York: Elsevier Science, 1994, 2111-2245.

Olson, M. "Rapid Growth as a Destabilizing Force." Journal of Economic History, 1963, 23(4), pp. $529-552$. 
SPAnish Ministry of Interior. Report about ETA, http://www.mir.es/oris/infoeta/indexin.htm, 2000.

The Economist. Robust Basques and Regional Catalans, Nov. 25, 2000.

Venieris, Y.P. And D. K. Gupta. "Income Distribution and Sociopolitical Instability as Determinants of Savings: A Cross-Sectional Model." Journal of Political Economy, 1986, 94(4), pp. 873-83. 


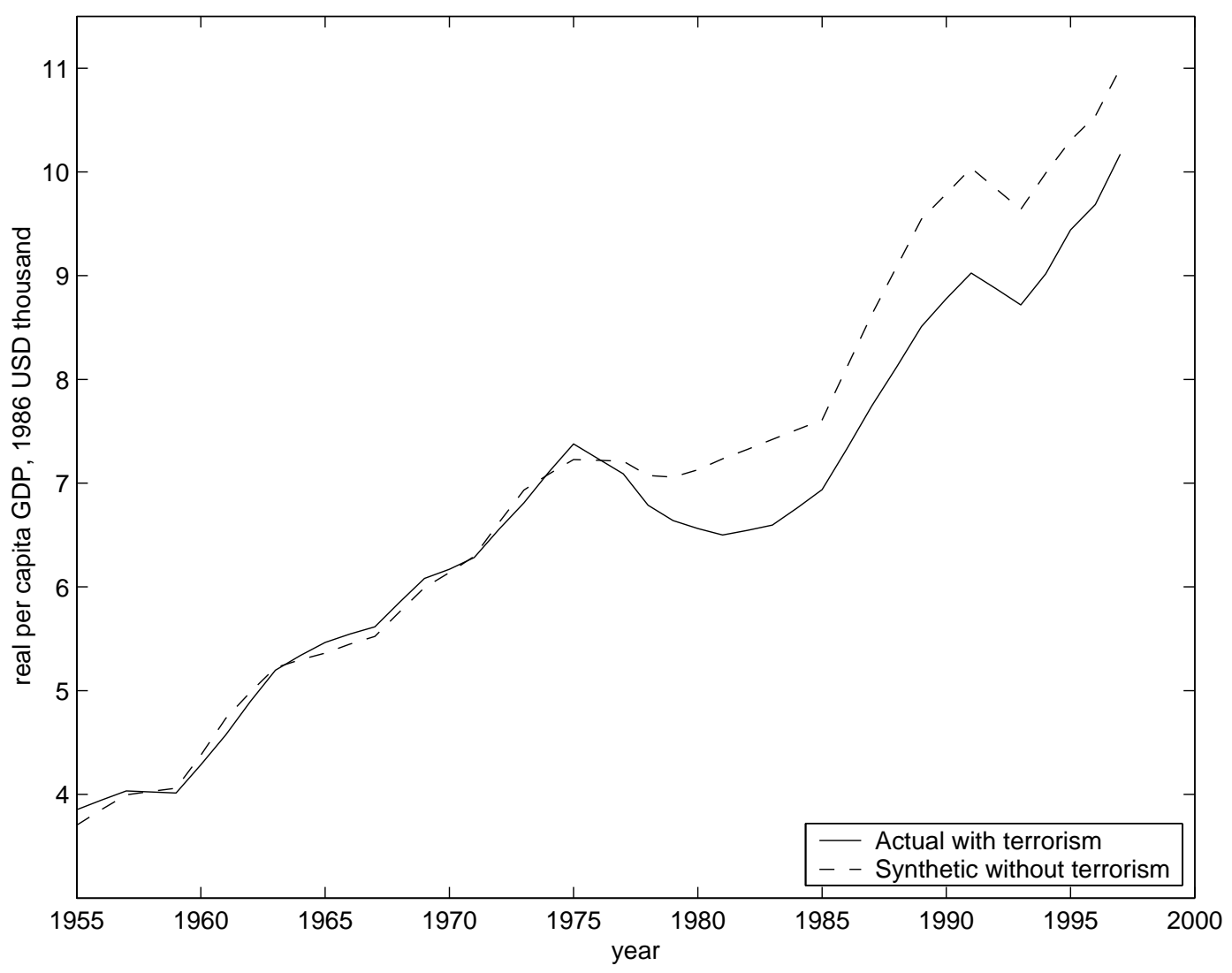

Figure 1. ACtual And COUnterfactual (Without terrorism) Per CApita GDP FOR THE BASQUe COUNTRY 


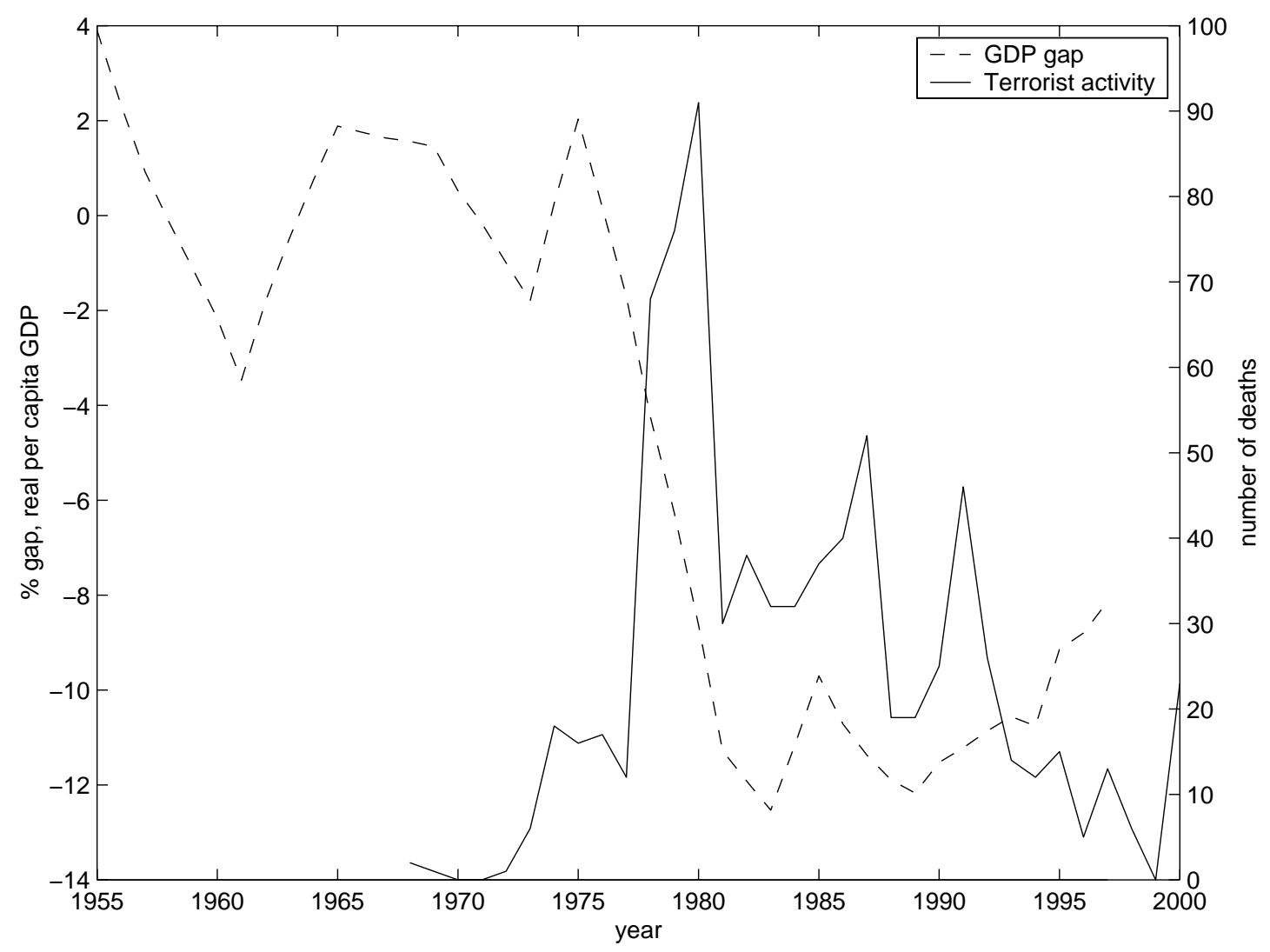

Figure 2. Terrorist aCtivity AND ESTIMATEd GaP 


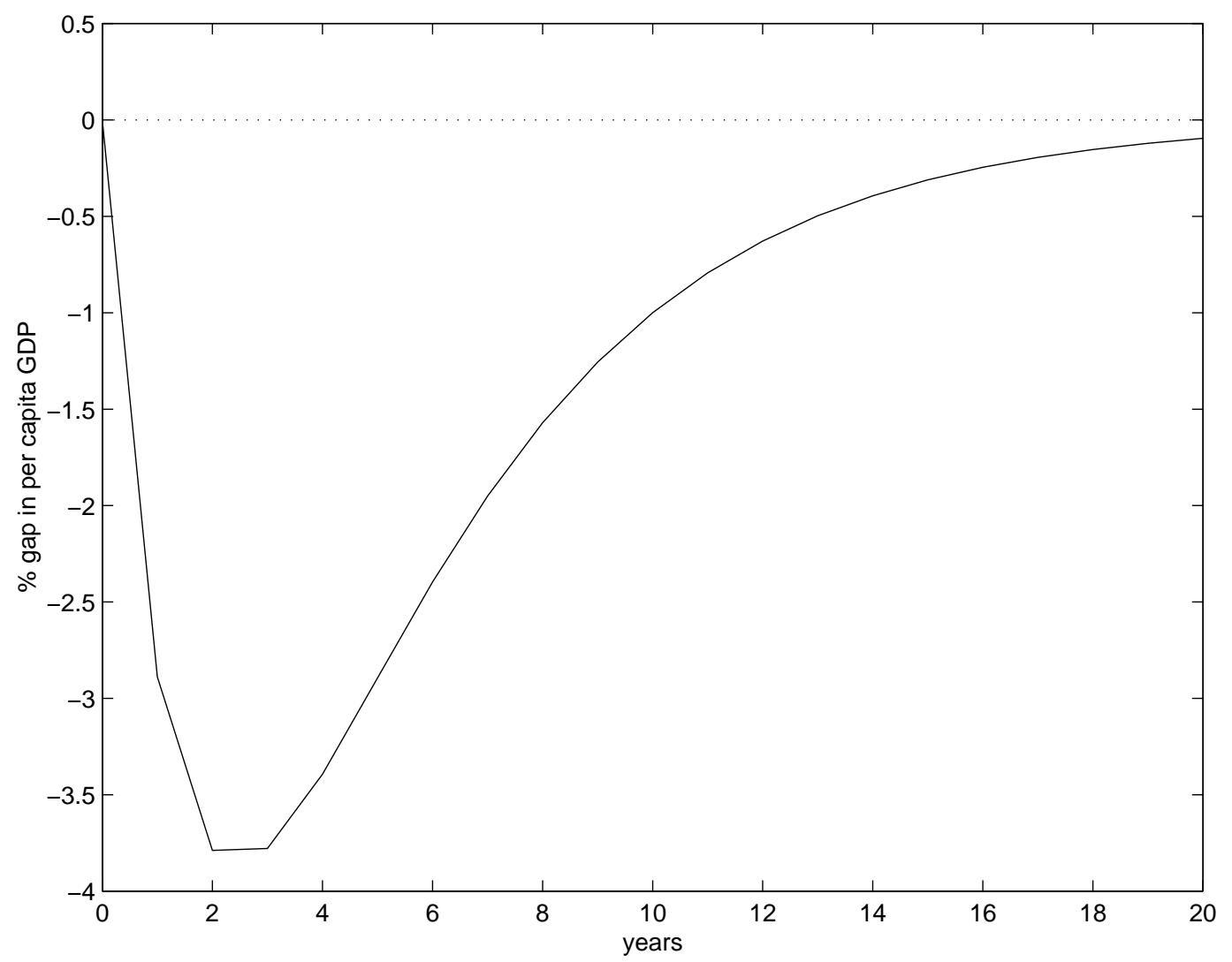

Figure 3. IMPULSE-RESPONSE FUNCTION FOR TERRORISM ON PER CAPITA GDP GAP 


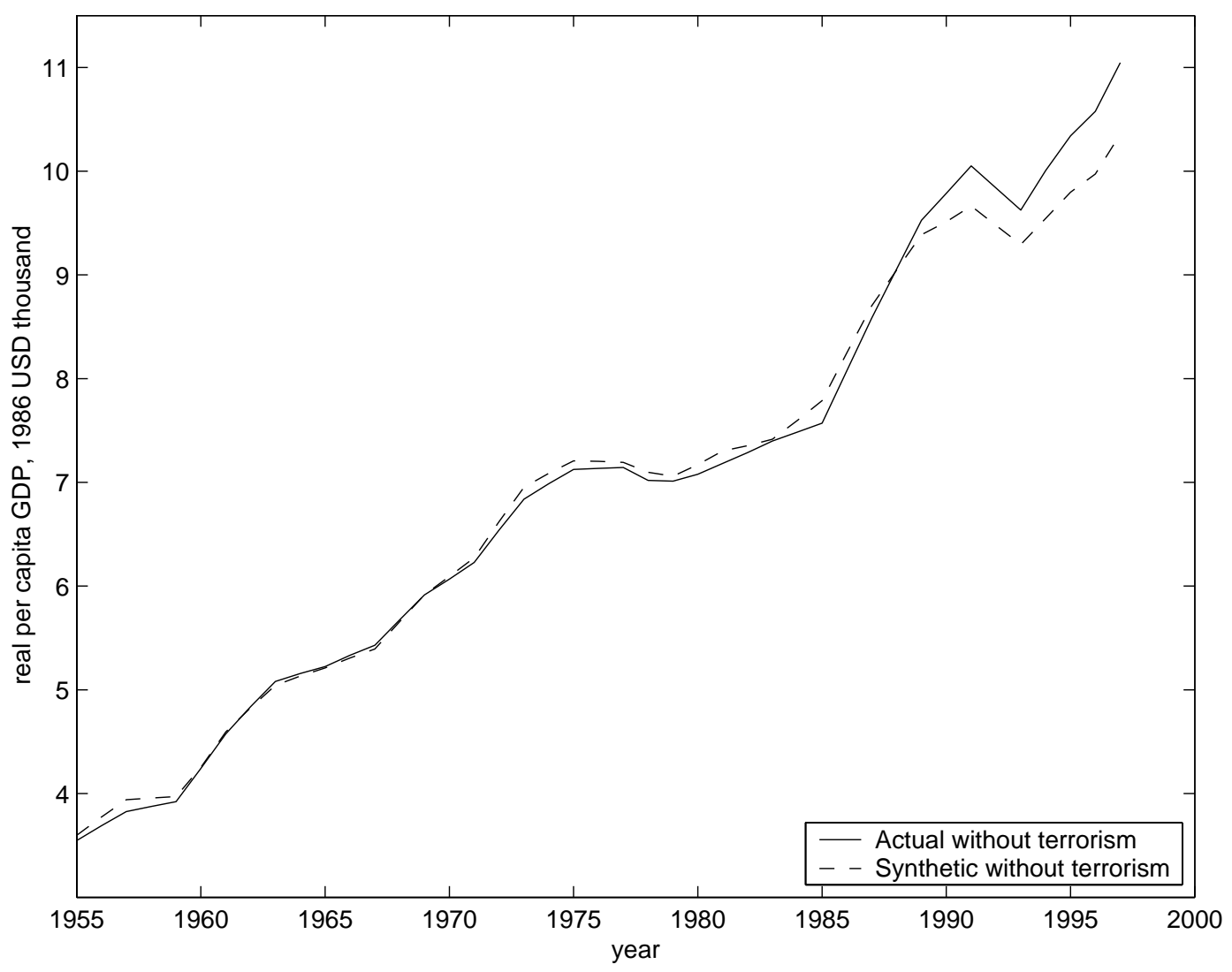

Figure 4. A "Placebo Study", Per CAPita GDP for Catalonia 


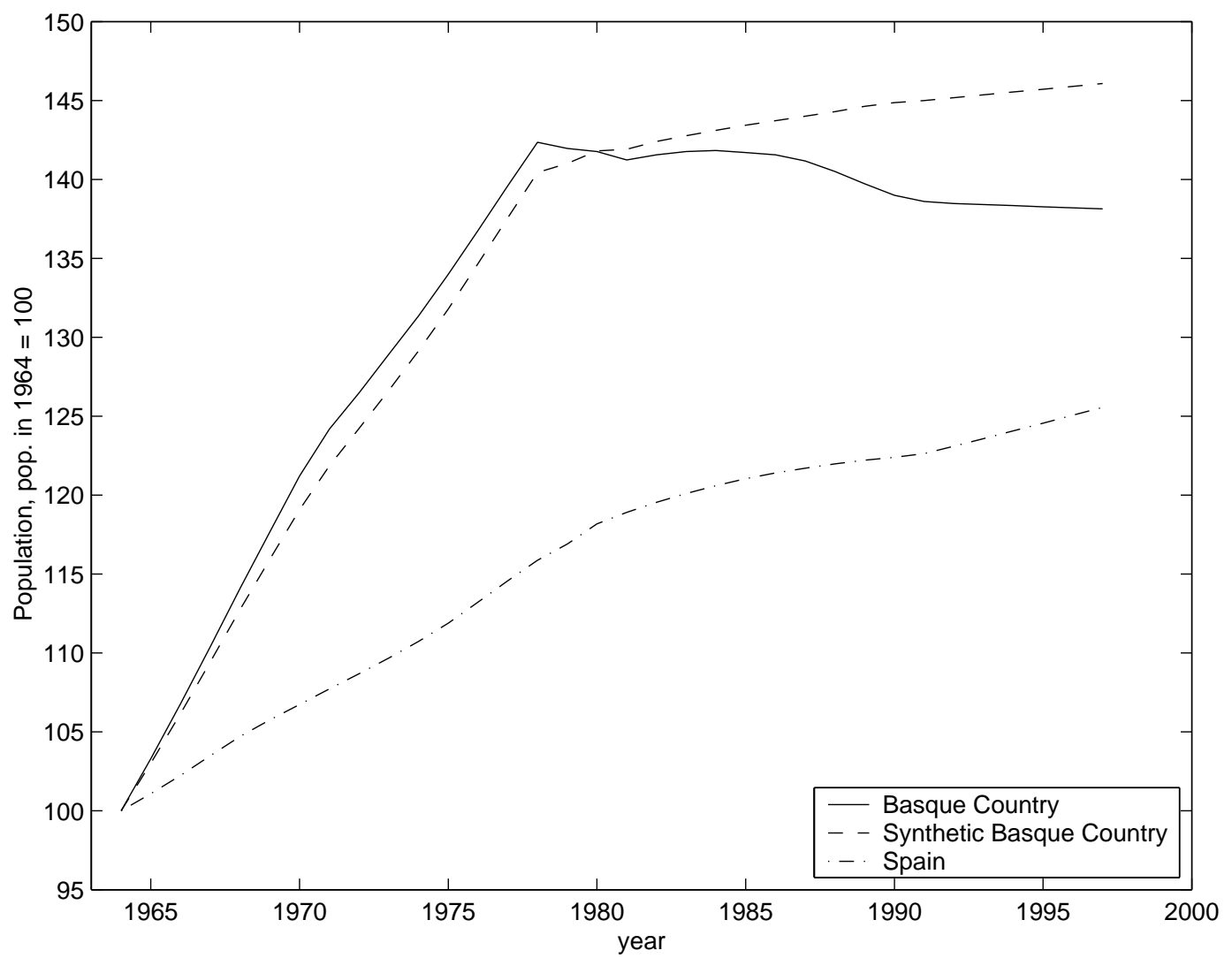

Figure 5. Population 


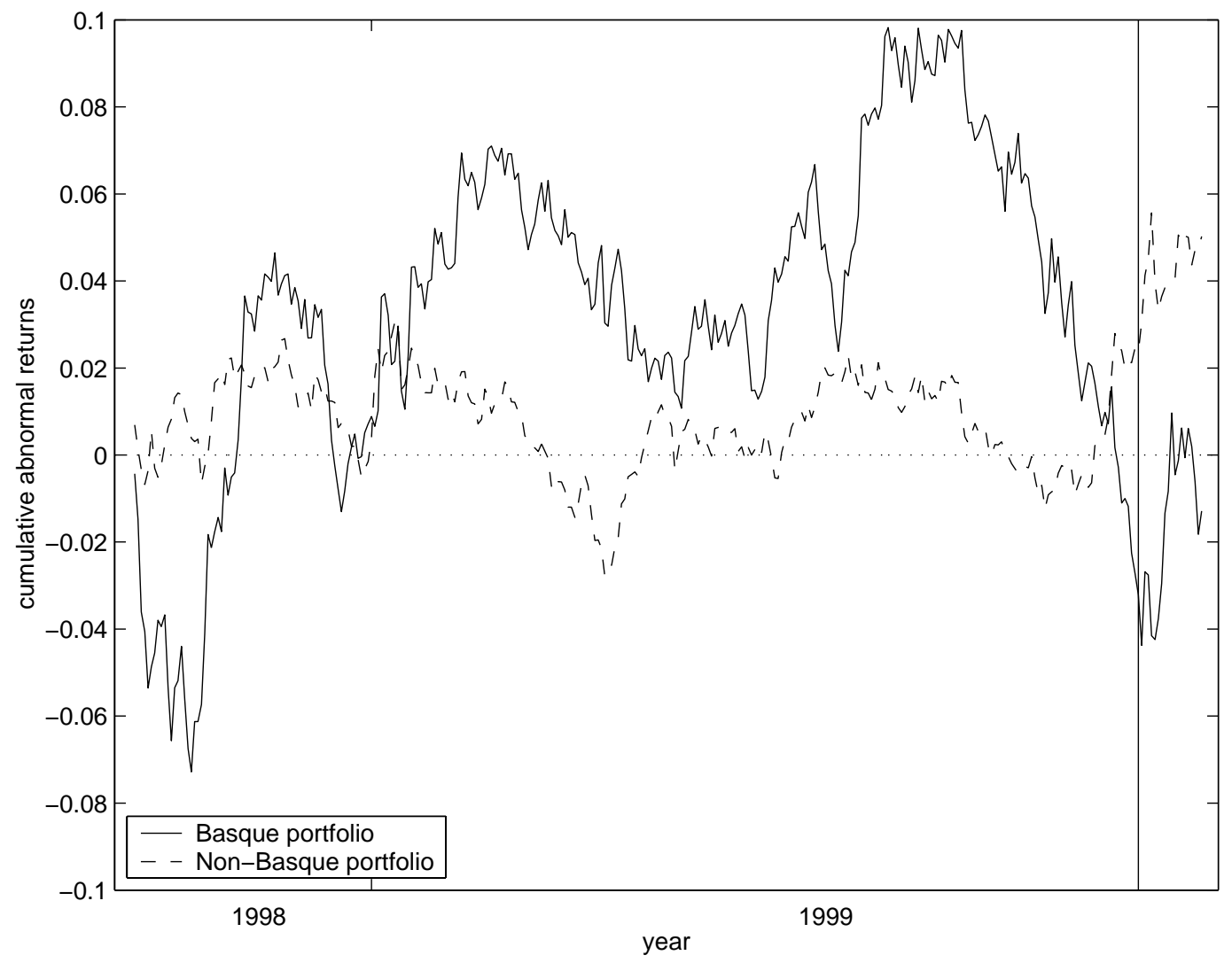

Figure 6. Cumulative Abnormal Portfolio Returns 
Table 1 - Chronology of ETA's Terrorist Activity

\begin{tabular}{|c|c|c|c|}
\hline Year & Killings & Kidnappings & Event \\
\hline 1968 & 2 & 0 & First victim of ETA \\
\hline 1969 & 1 & 0 & \\
\hline 1970 & 0 & 1 & \\
\hline 1971 & 0 & 0 & \\
\hline 1972 & 1 & 1 & \\
\hline 1973 & 6 & 1 & ETA kills Franco's Prime Minister Admiral Carrero-Blanco \\
\hline 1974 & 18 & 0 & \\
\hline 1975 & 16 & 0 & Dictator Franco dies \\
\hline 1976 & 17 & 4 & \\
\hline 1977 & 12 & 1 & First democratic elections in Spain after Franco's death \\
\hline 1978 & 68 & 6 & Spanish Constitution approved in referendum \\
\hline 1979 & 76 & 13 & Regional Autonomy Statute for the Basque Country approved \\
\hline 1980 & 91 & 13 & \\
\hline 1981 & 30 & 10 & \\
\hline 1982 & 38 & 8 & \\
\hline 1983 & 32 & 5 & \\
\hline 1984 & 32 & 0 & \\
\hline 1985 & 37 & 3 & \\
\hline 1986 & 40 & 3 & Spain joins European Community \\
\hline 1987 & 52 & 1 & \\
\hline 1988 & 19 & 1 & \\
\hline 1989 & 19 & 1 & \\
\hline 1990 & 25 & 0 & \\
\hline 1991 & 46 & 0 & \\
\hline 1992 & 26 & 0 & \\
\hline 1993 & 14 & 1 & \\
\hline 1994 & 12 & 0 & \\
\hline 1995 & 15 & 1 & \\
\hline 1996 & 5 & 2 & \\
\hline 1997 & 13 & 1 & \\
\hline 1998 & 6 & 0 & ETA declares indefinite cease-fire starting on Sept. 18 \\
\hline 1999 & 0 & 0 & ETA announces the end of cease-fire on Nov. 28 \\
\hline 2000 & 23 & 0 & \\
\hline
\end{tabular}

Source: Spanish Ministry of Interior (2000). 
TAble 2 - Pre-Terrorism Characteristics, 1960's

\begin{tabular}{|c|c|c|c|}
\hline & $\begin{array}{c}\text { Basque Country } \\
\text { (1) }\end{array}$ & $\begin{array}{l}\text { Spain } \\
(2)\end{array}$ & $\begin{array}{c}\text { "Synthetic" } \\
\text { Basque Country } \\
(3)\end{array}$ \\
\hline Real per capita GDP ${ }^{a}$ & $5,285.46$ & $3,633.25$ & $5,270.80$ \\
\hline Investment ratio $(\%)^{b}$ & 24.65 & 21.79 & 21.58 \\
\hline Population density ${ }^{c}$ & 246.89 & 66.34 & 196.28 \\
\hline \multicolumn{4}{|l|}{ Sectoral Shares $(\%)^{d}$} \\
\hline Agriculture, forestry and fishing & 6.84 & 16.34 & 6.18 \\
\hline Energy and water & 4.11 & 4.32 & 2.76 \\
\hline Industry & 45.08 & 26.60 & 37.64 \\
\hline Construction and engineering & 6.15 & 7.25 & 6.96 \\
\hline Marketable services & 33.75 & 38.53 & 41.10 \\
\hline Non marketable services & 4.07 & 6.97 & 5.37 \\
\hline \multicolumn{4}{|l|}{ Human Capital $(\%)^{e}$} \\
\hline Illiterates & 3.32 & 11.66 & 7.65 \\
\hline Primary or without studies & 85.97 & 80.15 & 82.33 \\
\hline High school & 7.46 & 5.49 & 6.92 \\
\hline More than high school & 3.26 & 2.70 & 3.10 \\
\hline
\end{tabular}

Sources: Authors' computations from Fundación BBV (1999) and Mas et al. (1998).

a 1986 USD, average for 1960-1969.

${ }^{b}$ Gross Total Investment/GDP, average for 1964-1969.

${ }^{c}$ Persons per square kilometer, 1969.

${ }^{d}$ Percentages over total production, 1961-1969.

${ }^{e}$ Percentages over working-age population, 1964-1969. 
Table 3 - Chronology of the Truce

\begin{tabular}{|c|c|c|}
\hline no & Date & Event \\
\hline 1 & Sept 12,1998 & $\begin{array}{l}\text { Basque nationalist parties (including ETA's political wing) sign joint declara- } \\
\text { tion calling for the end of violence }\end{array}$ \\
\hline 2 & Sept 15, 1998 & $\begin{array}{l}\text { Spanish Minister of Interior says the government expects "fake truce" by ETA } \\
\text { intended to regroup and gain popular support }\end{array}$ \\
\hline 3 & Sept 16,1998 & ETA calls cease-fire starting on Sept 18 \\
\hline 4 & Sept 17, 1998 & $\begin{array}{l}\text { Spanish government expresses "profound skepticism" about the truce and ad- } \\
\text { vises caution }\end{array}$ \\
\hline 5 & Oct 2, 1998 & $\begin{array}{l}\text { Spanish Prime Minister says ETA has yet to prove its commitment to peace, } \\
\text { but promises changes in policy towards incarcerated ETA activists if peace } \\
\text { consolidates }\end{array}$ \\
\hline 6 & Oct 24,1998 & ETA leaders say cease-fire is "firm and serious" in BBC TV broadcast \\
\hline 7 & Nov 3, 1998 & $\begin{array}{l}\text { Spanish government says it has authorized exploratory contacts with ETA in } \\
\text { order to assess ETA's commitment to maintain cease-fire }\end{array}$ \\
\hline 8 & Feb 24, 1999 & $\begin{array}{l}\text { ETA's communique pledges to maintain cease-fire and alludes to a new "hopeful } \\
\text { climate" }\end{array}$ \\
\hline 9 & May 16, 1999 & ETA says it has maintained contacts with Spanish government \\
\hline 10 & n 2, 1999 & ETA \\
\hline 11 & Aug 25, 1999 & Spanish Prime Minister says that contacts with ETA have been interrupted \\
\hline 12 & Aug 26, 1999 & is is paralyzed \\
\hline 13 & Aug 28, 1999 & $\begin{array}{l}\text { ETA's communique states that the peace process has reached a "critical stage" } \\
\text { in which it is either concluded "or else it will rot" }\end{array}$ \\
\hline 14 & Nov 28, 1999 & ETA announces the end of cease-fire \\
\hline
\end{tabular}


Table 4 - Descriptive Statistics

\begin{tabular}{|c|c|c|c|c|c|}
\hline & & & Basque & Non-Basque & All \\
\hline Number of obs. & & & 14 & 59 & 73 \\
\hline \multicolumn{6}{|l|}{ Registered in the } \\
\hline Basque Country & & Mean & 0.57 & 0.00 & 0.11 \\
\hline \multirow[t]{12}{*}{ Size } & 1997 & Mean & 412.28 & $1,999.37$ & $1,695.00$ \\
\hline & & S.D. & 362.84 & $4,501.26$ & $4,091.61$ \\
\hline & & Min & 117.66 & 17.01 & 17.01 \\
\hline & & $\operatorname{Max}$ & $1,531.68$ & $26,778.68$ & $26,778.68$ \\
\hline & 1998 & Mean & 478.70 & $2,948.63$ & $2,474.94$ \\
\hline & & S.D. & 348.46 & $7,105.34$ & $6,453.67$ \\
\hline & & Min & 104.56 & 15.88 & 15.88 \\
\hline & & Max & $1,244.64$ & $45,347.23$ & $45,347.23$ \\
\hline & 1999 & Mean & 371.43 & $3,346.84$ & $2,776.21$ \\
\hline & & S.D. & 406.43 & $11,305.43$ & $10,216.72$ \\
\hline & & Min & 56.20 & 9.12 & 9.12 \\
\hline & & Max & $1,656.38$ & $81,292.33$ & $81,292.33$ \\
\hline \multirow[t]{12}{*}{ Book-to-Market } & 1997 & Mean & 0.68 & 0.55 & 0.58 \\
\hline & & S.D. & 0.43 & 0.34 & 0.36 \\
\hline & & Min & 0.20 & 0.09 & 0.09 \\
\hline & & Max & 1.65 & 1.80 & 1.80 \\
\hline & 1998 & Mean & 0.72 & 0.50 & 0.54 \\
\hline & & S.D. & 0.55 & 0.29 & 0.36 \\
\hline & & Min & 0.14 & 0.07 & 0.07 \\
\hline & & $\operatorname{Max}$ & 2.28 & 1.38 & 2.28 \\
\hline & 1999 & Mean & 0.86 & 0.68 & 0.71 \\
\hline & & S.D. & 0.46 & 0.43 & 0.44 \\
\hline & & Min & 0.30 & 0.08 & 0.08 \\
\hline & & $\operatorname{Max}$ & 1.70 & 2.26 & 2.26 \\
\hline
\end{tabular}

Source: Authors' computations from Madrid Stock Exchange on-line data (http://www.bolsamadrid.es). Size values in millions of USD. For conversion, each USD figure was obtained using the Peseta/Dollar (1997) and Euro/Dollar (1998 and 1999) exchange rates of the last day of the year. 
Table 5 - Portfolio Regressions

\begin{tabular}{|c|c|c|c|c|c|}
\hline & $\begin{array}{c}\text { Basque } \\
(1)\end{array}$ & $\begin{array}{c}\text { Non-Basque } \\
(2)\end{array}$ & $\begin{array}{c}\text { Basque } \\
(3)\end{array}$ & $\begin{array}{c}\text { Non-Basque } \\
(4)\end{array}$ & $\begin{array}{c}\text { Difference } \\
(3)-(4)\end{array}$ \\
\hline Constant & $\begin{array}{l}-.0004 \\
(.0003)\end{array}$ & $\begin{array}{c}.0001 \\
(.0002)\end{array}$ & $\begin{array}{l}-.0004 \\
(.0003)\end{array}$ & $\begin{array}{l}.0001 \\
(.0002)\end{array}$ & $\begin{array}{l}-.0005 \\
(.0003)\end{array}$ \\
\hline $\mathrm{R}^{m}$ & $\begin{array}{c}.6824 \\
(.0360)\end{array}$ & $\begin{array}{l}.8103 \\
(.0184)\end{array}$ & $\begin{array}{l}.6739 \\
(.0365)\end{array}$ & $\begin{array}{c}.8096 \\
(.0185)\end{array}$ & $\begin{array}{l}-.1356 \\
(.0345)\end{array}$ \\
\hline SMB & $\begin{array}{l}.3758 \\
(.0460)\end{array}$ & $\begin{array}{l}-.2252 \\
(.0233)\end{array}$ & $\begin{array}{c}.3659 \\
(.0462)\end{array}$ & $\begin{array}{l}-.2259 \\
(.0234)\end{array}$ & $\begin{array}{l}.5918 \\
(.0443)\end{array}$ \\
\hline HML & $\begin{array}{l}.2506 \\
(.0398)\end{array}$ & $\begin{array}{l}-.1419 \\
(.0206)\end{array}$ & $\begin{array}{c}.2549 \\
(.0398)\end{array}$ & $\begin{array}{l}-.1412 \\
(.0207)\end{array}$ & $\begin{array}{c}.3961 \\
(.0380)\end{array}$ \\
\hline Good News & & & $\begin{array}{c}.0049 \\
(.0021)\end{array}$ & $\begin{array}{l}.0005 \\
(.0009)\end{array}$ & $\begin{array}{c}.0044 \\
(.0022)\end{array}$ \\
\hline Bad News & & & $\begin{array}{l}-.0017 \\
(.0008)\end{array}$ & $\begin{array}{l}.0001 \\
(.0004)\end{array}$ & $\begin{array}{l}-.0018 \\
(.0009)\end{array}$ \\
\hline
\end{tabular}

Note: Heteroskedasticity-robust standard errors in parentheses. 
Table A.1 - Estimation of the Impulse-Response Function

\begin{tabular}{lccccc}
\hline \hline & $(1)$ & $(2)$ & $(3)$ & $(4)$ & $(5)$ \\
\hline$\mu$ & -0.2590 & -0.0834 & -0.0923 & -0.1233 & - \\
& $(0.2204)$ & $(0.2081)$ & $(0.2084)$ & $(0.2137)$ & \\
$\alpha_{1}$ & 1.3582 & 1.2163 & 1.2823 & 1.3018 & 1.3115 \\
& $(0.2550)$ & $(0.2111)$ & $(0.1902)$ & $(0.1863)$ & $(0.1822)$ \\
$\alpha_{2}$ & -0.4555 & -0.3507 & -0.3928 & -0.4099 & -0.4121 \\
& $(0.2331)$ & $(0.1815)$ & $(0.1684)$ & $(0.1663)$ & $(0.1645)$ \\
$\beta_{0}$ & -0.0006 & -0.0074 & -0.0070 & - & - \\
& $(0.0079)$ & $(0.0090)$ & $(0.0092)$ & & \\
$\beta_{1}$ & -0.0204 & -0.0162 & -0.0230 & -0.0277 & -0.0289 \\
& $(0.0089)$ & $(0.0091)$ & $(0.0091)$ & $(0.0081)$ & $(0.0082)$ \\
$\beta_{2}$ & -0.0009 & -0.0139 & - & - & - \\
& $(0.0087)$ & $(0.0108)$ & & & \\
$\rho$ & 0.0858 & - & - & - & - \\
$\mathrm{R}^{2}$ & $(0.2509)$ & & & & \\
\hline
\end{tabular}

Note: Estimates of the parameters in equation (A.1). Standard errors in parentheses. 
Table A.2 - List of Stocks

\begin{tabular}{|c|c|c|c|}
\hline \multicolumn{4}{|c|}{ Basque Stocks } \\
\hline $\mathrm{ACR}$ & Aceralia Corporación Siderúrgica, S.A. & FAE & Faes Fábrica Esp. Prod. Químicos y Farma. \\
\hline ASA & Tavex Algodonera, S.A. & GUI & Banco Guipuzcoano, S.A. \\
\hline AZK & Azkoyen S.A. & KOI & Koipe, S.A. \\
\hline BYB & Bodegas y Bebidas, S.A. & TUB & Tubacex,S.A. \\
\hline $\mathrm{CAF}$ & Construcciones y Auxiliar de Ferrocarril & VAS & Banco de Vasconia, S.A. \\
\hline CPL & Cementos Portland & VID & Vidrala, S.A. \\
\hline EUR & Europistas Concesionaria Española, S.A. & VIS & Viscofan, S.A. \\
\hline \multicolumn{4}{|c|}{ Non-Basque Stocks } \\
\hline $\mathrm{ACE}$ & Autopistas Concesionaria Española, S.A. & GCO & Catalana Occidente, S.A. \\
\hline ACS & Actividades de Const. y Servicios S.A. & GPP & Grupo Picking Pack, S.A. \\
\hline $\mathrm{ACX}$ & Acerinox, S.A. & IBG & Iberpapel Gestión, S.A. \\
\hline ADZ & Adolfo Domínguez, S.A. & MAP & Corporación Mapfre, Cia. Int. de Reaseguros \\
\hline AGS & Sdad. General Aguas de Barcelona, S.A. & $\mathrm{MDF}$ & Grupo Duro Felguera, S.A. \\
\hline ALB & Corporación Financiera Alba, S.A. & MPV & Mapfre Vida, S.A. \\
\hline ALD & Aldeasa, S.A. & MVC & Metrovacesa, S.A. \\
\hline ANA & Acciona, S.A. & NEA & Nicolas Correa, S.A. \\
\hline AND & Banco de Andalucía & NMQ & Nueva Montaña de Quijano, S.A. \\
\hline ARA & Energía e Industrias Aragonesas, S.A. & PAS & Banco Pastor, S.A. \\
\hline $\mathrm{AZC}$ & Asturiana del Zinc, S.A. & PIN & Prima Inmobiliaria, S.A. \\
\hline BAM & Bami, S.A. Inmobiliaria de Construcciones & POP & Banco Popular Español, S.A. \\
\hline $\mathrm{BKT}$ & Bankinter, S.A. & PSG & Prosegur, S.A., Cia. de Seguridad \\
\hline BVA & Banco de Valencia, S.A. & PUL & Puleva, S.A. \\
\hline CAN & Hidroeléctrica del Cantábrico, S.A. & REP & Repsol, S.A. \\
\hline CAS & Banco de Castilla, S.A. & $\mathrm{RIO}$ & Bodegas Riojanas, S.A. \\
\hline CBL & Banco de Crédito Balear, S.A. & SED & Seda de Barcelona, S.A. (LA) \\
\hline CEP & Cia. Española de Petroleos, S.A. & $\mathrm{SOL}$ & Sol Meliá, S.A. \\
\hline $\mathrm{CPF}$ & Campofrio Alimentación, S.A. & TEF & Telefónica, S.A. \\
\hline CRI & Cristaleria Española, S.A. & UBS & Urbanizaciones y Transportes, S.A. \\
\hline CTF & Cortefiel, S.A. & UNF & Unión Eléctrica-Fenosa, S.A. \\
\hline CTG & Gas Natural SDG, S.A. (Catalana Gas) & UPL & Unipapel, S.A. \\
\hline DIN & Dinamia Capital Privado, S.A. & URA & Uralita, S.A. \\
\hline $\mathrm{DRC}$ & Grupo Dragados, S.A. & URB & Inmobiliaria Urbis, S.A. \\
\hline ECR & Ercros S.A. & VAL & Vallehermoso, S.A. \\
\hline ELE & Endesa, S.A. & VDR & Portland Valderrivas, S.A. \\
\hline ENC & Grupo Empresarial Ence, S.A. & $\mathrm{ZNC}$ & Española del Zinc, S.A. \\
\hline FCC & Fomento de Construcciones y Contratas, S.A. & $\mathrm{ZOT}$ & Zardoya Otis, S.A. \\
\hline FIL & Filo, S.A. & $\mathrm{ZRG}$ & Banco Zaragozano, S.A. \\
\hline GAL & Banco de Galicia, S.A. & & \\
\hline
\end{tabular}

